\title{
Article \\ Relationship between Serum 25OH-Vitamin D2 Level and Vitamin D Status of Children Aged 3-5 Years in China
}

\author{
Xuehong Pang $\mathbb{D}^{\mathbb{D}}$, Zhenyu Yang *, Jie Wang, Yifan Duan $\mathbb{D}^{\mathbb{D}}$, Liyun Zhao, Dongmei Yu and Jianqiang Lai
}

Key Laboratory of Trace Element Nutrition of National Health Commission, National Institute for Nutrition and Health, Chinese Center for Disease Control and Prevention, Beijing 100050, China; pangxh@ninh.chinacdc.cn (X.P.); wangjie@ninh.chinacdc.cn (J.W.); duanyf@ninh.chinacdc.cn (Y.D.); zhaoly@ninh.chinacdc.cn (L.Z.); yudm@ninh.chinacdc.cn (D.Y.); laijq@ninh.chinacdc.cn (J.L.)

* Correspondence: yangzy@ninh.chinacdc.cn; Tel.: +86-10-66237198

check for updates

Citation: Pang, X.; Yang, Z.; Wang, J.; Duan, Y.; Zhao, L.; Yu, D.; Lai, J. Relationship between Serum 25OH-Vitamin D2 Level and Vitamin D Status of Children Aged 3-5 Years in China. Nutrients 2021, 13, 4135. https://doi.org/10.3390/nu13114135

Academic Editor: Bruce W. Hollis

Received: 15 October 2021

Accepted: 12 November 2021

Published: 19 November 2021

Publisher's Note: MDPI stays neutral with regard to jurisdictional claims in published maps and institutional affiliations.

Copyright: (c) 2021 by the authors. Licensee MDPI, Basel, Switzerland. This article is an open access article distributed under the terms and conditions of the Creative Commons Attribution (CC BY) license (https:// creativecommons.org/licenses/by/ $4.0 /)$.
Abstract: Background: Vitamin D deficiency is prevalent globally and there is lack of evidence as to how $25(\mathrm{OH}) \mathrm{D} 2$ contributes to vitamin $\mathrm{D}$ status. The aim of this study was to describe vitamin $\mathrm{D}$ status and to assess the role of vitamin D2, a dietary vitamin D source, against the vitamin D status of children aged 3-5 years in China. Methods: Data were extracted from the Chinese National Nutrition and Health Surveillance (CNNHS) in 2013. The concentration of serum 25(OH)D2 and 25(OH)D3 was measured by using LC-MS/MS. Results: A total of 1435 subjects were enrolled and serum $25(\mathrm{OH}) \mathrm{D}$ were analyzed. The prevalence of total serum $25(\mathrm{OH}) \mathrm{D}<30 \mathrm{nmol} / \mathrm{L}$ was $8.9 \%$. Serum $25(\mathrm{OH}) \mathrm{D} 2$ was detected in $10.9 \%$ of the studied children. After adjusting for confounding factors, total $25(\mathrm{OH}) \mathrm{D}$ concentration was $8.48 \mathrm{nmol} / \mathrm{L}$ lower and odds ratio of vitamin D deficiency was 4.20 times (OR $(95 \% \mathrm{CI}): 4.20(1.64,10.77))$ in children without $25(\mathrm{OH}) \mathrm{D} 2$ than those with $25(\mathrm{OH}) \mathrm{D} 2$ detected. Conclusions: Vitamin D deficiency was common among children aged 3-5 years in China. Vitamin D2 may play a role in preventing vitamin D deficiency in Chinese children aged 3-5 years.

Keywords: China; cross-sectional study; preschool children; 25-hydroxvitamin D2; 25-hydroxvitamin D

\section{Introduction}

Vitamin D is a critical vitamin that regulates calcium, phosphorus [1] and bone metabolism [2]. Vitamin D deficiency early in life has been associated with decreased muscle strength [3], nutritional rickets, dental caries [4], sleep-disordered breathing [5], respiratory infections [6,7] and a more diverse lipid profile [8] in children. Higher serum $25(\mathrm{OH}) \mathrm{D}$ levels in youth have been associated with a reduced risk of developing type 2 diabetes mellitus [9], hypertension [10], cardiovascular disease [11] and cancer [12] later in adulthood.

Vitamin D insufficiency is common in China. The prevalence of vitamin D insufficiency $(25(\mathrm{OH}) \mathrm{D}<50 \mathrm{nmol} / \mathrm{L})$ was reported to be $53.2 \%$ for Chinese children and adolescents aged 6-17 years in 2010-2012 [13]. Children aged 3-5 years are at the critical stage of growth. Currently, there is no nationwide prevalence on vitamin $\mathrm{D}$ deficiency for preschool children in China.

Vitamin D includes both vitamin D2 and vitamin D3. It is commonly considered that human vitamin $\mathrm{D}$ is mainly produced by skin through sunlight exposure, with a small amount coming through dietary intake, as it naturally is not present in many foods [14,15]. Sometimes vitamin $\mathrm{D}$ is even considered as a hormone rather than a nutrient. Vitamin D3 in the body comes from synthesis in the skin through sunlight exposure, nutrient supplementation and some animal source foods, such as fatty fish, fish liver oils and egg yolk [16]. Vitamin D2 in the body comes from nutrient supplements and dietary intake, mainly present in plants, plant products [17] and some meat of grazing animals [18]. Some research has found that vitamin D3 is more efficacious in raising total serum $25(\mathrm{OH}) \mathrm{D}$ concentration than vitamin D2 [19]. However, the evidence on how vitamins D2 contributes 
to vitamin D status is less clear. The aim of this study is to evaluate the vitamin D status of preschool children in China and to explore the role of vitamin D2 in vitamin D status.

\section{Materials and Methods}

\subsection{Study Design}

Data were collected from the Chinese National Nutrition and Health Surveillance in 2013 (CNNHS). The detailed methods of CNNHS 2013 were described previously [20,21]. Briefly, it was a cross-sectional survey with using a multi-stage stratified cluster sampling method. At the first stage, 2865 districts/counties from 30 provinces in China (Tibet autonomous region was not included) were classified into four categories, namely metropolises, medium and small cities, non-poor rural areas and poor rural areas. Then, 55 sites (12 metropolises, 15 medium and small cities, 18 non-poor rural areas, and 10 poor rural areas) were selected in the study based on proportion to population size. Then, 270 children aged 3-5 years were selected from each site, which was 90 in each age group (36-47 months, 48-59 months, and $60-71$ months). A total of 14,850 children aged $3-5$ years ( 36 to $<72$ months) were recruited, of whom at least 30 children at each site were sampled to assess their vitamin D status. The planned samples size for vitamin D was 1650 . However, some parents refused to collect blood for children and some blood samples were not enough for vitamin D analysis.

\subsection{Data Collection}

The primary caregivers of children aged 3-5 years were interviewed using face-to-face interview by well-trained staff. A standardized questionnaire was used to collect the information of socioeconomic, family, lifestyle, health-related information, food frequency and supplement use information in the past week. A standard stadiometer and electronic weighting scale (Tc-200 K) were used to measure the height and weight respectively, without shoes, hat, heavy coat and untied hair.

\subsection{Blood Sample and 25-Hydroxyvitamin D Measurement}

Fasting venous blood $(4 \mathrm{~mL})$ was collected into vacutainer tubes (Becton Dickinson) containing potassium ethylene diamine tetraacetic acid (EDTA -K2), and then the samples were centrifuged at $1500 \times g$ for $15 \mathrm{~min}$ within 30-60 min. The serum used to test for vitamin $\mathrm{D}$ was aliquoted and stored in a brown centrifuge tube at $-20 \sim-80{ }^{\circ} \mathrm{C}$ in the local laboratory. All samples from the 55 study sites were transported to the National Institution for Nutrition and Health, China CDC by using cold chain. All the samples were preserved at $-80{ }^{\circ} \mathrm{C}$ refrigerator until analysis. Serum 25(OH)D2 and 25(OH)D3 concentration were measured in qualified laboratory by liquid chromatography-mass spectrometry (LC-MS/MS, API 4000 Plus, AB SCIEX, USA). The LOD (limit of detection) of 25(OH)D2 and 25(OH)D3 were $2.45 \mathrm{nmol} / \mathrm{L}$ and $1.13 \mathrm{nmol} / \mathrm{L}$, respectively. Both low and high concentration of quality control standards (RECIPE, Germany) of 25(OH)D2 and $25(\mathrm{OH}) \mathrm{D} 3$ were analyzed in every run. Inter-run coefficients of variations $(\mathrm{CVs})$ for serum quality-control pools were $3.47 \%$ and $3.10 \%$ for low concentration and high concentration for $25(\mathrm{OH}) \mathrm{D} 2$ and $3.49 \%$ and $3.24 \%$ for low concentration and high concentration for $25(\mathrm{OH}) \mathrm{D} 3$, respectively.

\subsection{Definitions of Study Variables}

Total serum 25(OH)D concentration was the sum of serum 25(OH)D2 concentration and $25(\mathrm{OH}) \mathrm{D} 3$ concentration [22]. Total vitamin D concentration $<30 \mathrm{nmol} / \mathrm{L}$ is defined as vitamin D deficiency according to the Institution of Medicine (IOM) [23]. Based on the WHO growth standard in 2006 [24,25], wasting was defined as WHZ (weight-for-height Z-score) $<-2$, overweight was defined as $2<\mathrm{WHZ} \leq 3$, and obesity was defined as WHZ $>3$, respectively. Urban areas included both metropolises and medium/small cities. Rural areas included both non-poor rural areas and poor rural areas. A family's annual income per capita less than 15,000 CNY (Chinese Yuan) was defined as low income, $15,000-29,999 \mathrm{CNY}$ as middle income, and more than 30,000 CNY as high income. Low 
latitude is defined as $20^{\circ} \mathrm{N} \leq$ latitude $<30^{\circ} \mathrm{N}$, middle latitude as $30^{\circ} \mathrm{N} \leq$ latitude $<35^{\circ} \mathrm{N}$, and high latitude as latitude $\geq 35^{\circ} \mathrm{N}[26,27]$. The ethnicity was grouped according to their dressing habit. For example, the Muslin population have a covered clothing style, which may limit exposure of skin to natural light, whereas the Han population have an uncovered clothing style.

\subsection{Statistical Analyses}

Prevalence of vitamin D deficiency was presented as percentages (\%(95\% CI)) and concentration of 25(OH)D was described as median (P25,P75). Difference between 25(OH)D concentration was compared by Wilcoxon rank sum test or Kruskal-Wallis H rank sum test according to the classification of two or more groups. Chi-square test was used for categorical variables. Multiple linear regression was used to analyze the association between $25(\mathrm{OH}) \mathrm{D}$ concentration and potential related factors. Multiple logistic regression was performed to analyze associated risk factors for vitamin D deficiency. The variables included in the models were found to be significantly different in the concentration of vitamin D and vitamin D deficiency between different groups. The stepwise regression method was used for model selection (significance level for entry (SLE) $=0.20$, significance level for stay $(\mathrm{SLS})=0.05$ ). All statistical analyses were performed by SAS 9.4 software (SAS Institute Inc., Cary, NC, USA). The difference was considered as statistically significance with $p<0.05$.

\section{Results}

\subsection{Demographic Characteristics}

In total, serum vitamin D was measured in 1481 children aged 3-5 years, 46 samples collected from April to September were excluded because the samples collected during these months were too scattered and the interaction between latitude and survey month could not be analyzed. Finally, 1435 children were included in the current study, $83.6 \%$ $(1199 / 1435)$ of whom were Han ethnic and 2.2\% (31/1435) of whom were Muslin ethnic. The percentage of subjects was similar across different latitude groups and almost all of field work was completed in fall/winter (from October to January) (Table 1).

\subsection{Concentrations of Vitamin D and the Prevalence of Vitamin D Deficiency}

Twenty-five hydroxy-vitamin D3 existed in all children's blood sample, but 25(OH)D2 was only detected in $10.9 \%(156 / 1435)$ of the samples. The medians of serum $25(\mathrm{OH}) \mathrm{D} 3$ and total 25(OH)D for all children were $47.5(37.5,57.3) \mathrm{nmol} / \mathrm{L}$ and $49.3(39.0,58.5) \mathrm{nmol} / \mathrm{L}$, respectively. The concentration of $25(\mathrm{OH}) \mathrm{D} 2,25(\mathrm{OH}) \mathrm{D} 3$ and total $25(\mathrm{OH}) \mathrm{D}$ were 10.1 (7.1, $16.0) \mathrm{nmol} / \mathrm{L}, 41.8(38.3,57.8)$ and $55.0(46.8,65.8) \mathrm{nmol} / \mathrm{L}$ in the group with vitamin $\mathrm{D} 2$ detected, respectively. The prevalence of children suffered from vitamin D deficiency was $8.9 \%$, which was $3.2 \%$ in the group with vitamin D2 detected and 9.5\% in the group without vitamin D2 detected (Table 1).

Table 1. Vitamin D status and prevalence of vitamin D deficiency of children by demographic characteristics in China.

\begin{tabular}{|c|c|c|c|c|c|c|c|}
\hline & \multirow[b]{2}{*}{ Characteristics (N) } & \multicolumn{4}{|c|}{$\begin{array}{c}\text { Concentration } \\
\text { Median (P25, P75) (nmol/L) }\end{array}$} & \multicolumn{2}{|c|}{ Vitamin D Deficiency * } \\
\hline & & $\begin{array}{c}\# \text { of } \\
\text { 25(OH)D2 } \\
\text { Detected }\end{array}$ & 25(OH)D2 & 25(OH)D3 & 25(OH)D & $\begin{array}{l}\text { \# of } \\
\text { Case }\end{array}$ & $\%(95 \%$ CI $)$ \\
\hline Total & 1435 & 156 & $10.1(7.1,16.0)$ & $47.5(37.5,57.3)$ & $49.3(39.0,58.5)$ & 127 & $8.9(7.4,10.3)$ \\
\hline \multicolumn{8}{|c|}{ Vitamin D2 detected ${ }^{\mathrm{a}, \mathrm{b}}$} \\
\hline Yes & 156 & 156 & $10.1(7.1,16.0)$ & $41.8(38.3,57.8)$ & $55.0(46.8,65.8)$ & 5 & $3.2(0.4,6.0)$ \\
\hline No & 1279 & 0 & 0 & $48.3(38.3,57.8)$ & $48.3(38.3,57.8)$ & 122 & $9.5(7.9,11.2)$ \\
\hline \multicolumn{8}{|l|}{ Age $^{a}$} \\
\hline 3 year & 483 & 70 & $9.8(7.5,19.8)$ & $51.0(40.5,59.8)$ & $53.0(43.3,62.5)$ & 35 & $7.3(4.9,9.6)$ \\
\hline 4 year & 481 & 52 & $10.3(6.9,14.1)$ & $46.3(36.5,55.3)$ & $47.5(37.5,57.0)$ & 48 & $10.0(7.3,12.7)$ \\
\hline 5 year & 471 & 34 & $10.4(7.3,16.5)$ & $45.5(36.5,56.0)$ & $46.8(37.5,56.8)$ & 44 & $9.3(6.7,12.0)$ \\
\hline
\end{tabular}


Table 1. Cont

\begin{tabular}{|c|c|c|c|c|c|c|c|}
\hline & \multirow[b]{2}{*}{ Characteristics (N) } & \multicolumn{4}{|c|}{$\begin{array}{c}\text { Concentration } \\
\text { Median (P25, P75) (nmol/L) }\end{array}$} & \multicolumn{2}{|c|}{ Vitamin D Deficiency * } \\
\hline & & $\begin{array}{c}\# \text { of } \\
\text { 25(OH)D2 } \\
\text { Detected }\end{array}$ & $25(\mathrm{OH}) \mathrm{D} 2$ & 25(OH)D3 & 25(OH)D & $\begin{array}{l}\text { \# of } \\
\text { Case }\end{array}$ & $\%(95 \% \mathrm{CI})$ \\
\hline \multicolumn{8}{|l|}{$\operatorname{Sex}^{\mathrm{a}, \mathrm{b}}$} \\
\hline Boy & 720 & 82 & $9.8(7.0,16.3)$ & $49.6(38.8,59.3)$ & $51.3(40.3,60.8)$ & 48 & $6.7(4.8,8.5)$ \\
\hline Girl & 715 & 74 & $10.8(7.3,15.8)$ & $45.8(36.5,54.8)$ & $47.3(37.8,55.5)$ & 79 & $11.1(8.8,13.4)$ \\
\hline \multicolumn{8}{|l|}{ Preterm or not } \\
\hline No & 1266 & 133 & $10.3(7.0,15.8)$ & $47.5(37.8,57.0)$ & $49.0(39.3,58.3)$ & 111 & $8.8(7.2,10.3)$ \\
\hline Yes & 146 & 21 & $10.0(7.3,16.8)$ & $47.0(37.3,58.3)$ & $51.0(39.3,59.3)$ & 15 & $10.3(5.4,15.2)$ \\
\hline \multicolumn{8}{|l|}{ Ethnicity group ${ }^{a, b}$} \\
\hline Han & 1199 & 132 & $10.4(7.3,16.4)$ & $47.8(38.0,57.5)$ & $49.5(39.8,58.5)$ & 97 & $8.1(6.6,9.6)$ \\
\hline Muslin & 31 & 6 & $6.6(6.3,7.0)$ & $36.0(28.8,45.3)$ & $39.5(28.8,48.3)$ & 9 & $29.0(13.1,45.0)$ \\
\hline Others & 204 & 18 & $10.3(7.8,17.0)$ & $48.5(35.6,58.3)$ & $49.1(36.9,59.3)$ & 21 & $10.3(6.1,14.5)$ \\
\hline \multicolumn{8}{|l|}{ Body weight status } \\
\hline Wasting & 18 & 3 & $8.0(8.0,11.3)$ & $42.8(34.3,58.0)$ & $42.9(35.3,58.3)$ & 1 & $5.6(0,16.1)$ \\
\hline Normal & 1103 & 130 & $10.3(7.3,16.8)$ & $47.5(37.8,57.5)$ & $49.3(39.5,58.5)$ & 96 & $8.7(7.0-10.4)$ \\
\hline Overweight & 48 & 3 & $8.5(5.8,13.8)$ & $43.9(36.4,54.1)$ & $43.9(36.4,55.3)$ & 8 & $16.7(6.1-27.2)$ \\
\hline Obesity & 20 & 0 & 0 & $48.4(40.1,53.3)$ & $48.4(40.1,53.3)$ & 1 & $5.0(0,14.6)$ \\
\hline \multicolumn{8}{|l|}{ Residential area ${ }^{a, b}$} \\
\hline Rural & 717 & 67 & $10.5(7.0,15.8)$ & $49.8(40.3,59.5)$ & $50.8(41.3,61.0)$ & 35 & $4.9(3.3,6.5)$ \\
\hline Urban & 718 & 89 & $9.8(7.3,16.8)$ & $45.6(35.3,54.8)$ & $47.3(36.5,56.3)$ & 92 & $12.8(10.4,15.3)$ \\
\hline \multicolumn{8}{|l|}{ Outdoor time (per day) ${ }^{a}$} \\
\hline$\geq 2 \mathrm{~h}$ & 1033 & 96 & $10.4(7.0,17.3)$ & $48.8(38.3,58.3)$ & $50.5(40.0,59.5)$ & 86 & $8.3(6.6,10.0)$ \\
\hline$<2 \mathrm{~h}$ & 395 & 60 & $9.9(7.6,13.8)$ & $44.5(35.0,54.3)$ & $47.0(36.8,55.8)$ & 40 & $10.1(7.2,13.1)$ \\
\hline \multicolumn{8}{|l|}{ Family income } \\
\hline Low & 746 & 75 & $10.8(7.0,18.3)$ & $47.8(38.3,58.0)$ & $49.0(40.0,59.0)$ & 55 & $7.4(5.5,9.3)$ \\
\hline Medium & 292 & 30 & $8.5(6.8,12.8)$ & $47.8(37.8,56.1)$ & $49.3(38.1,58.3)$ & 30 & $10.3(6.8,13.8)$ \\
\hline High & 255 & 29 & $9.5(7.8,15)$ & $47.5(37.0,56.5)$ & $49.8(37.8,58.0)$ & 22 & $8.6(5.2,12.1)$ \\
\hline \multicolumn{8}{|l|}{ Latitude and survey month $\mathrm{a}, \mathrm{b}$} \\
\hline High latitude, October & 105 & 6 & $11.5(7.5,13.3)$ & $50.0(40.3,57.8)$ & $50.8(42.3,58.0)$ & 5 & $4.8(0.7,8.8)$ \\
\hline High latitude, November & 174 & 17 & $8.0(6.5,11.0)$ & $45.4(37.0,55.3)$ & $47.6(38.3,56.0)$ & 21 & $12.1(7.2,16.9)$ \\
\hline High latitude, December & 206 & 34 & $10.9(8.0,15.8)$ & $36.3(28.3,47.3)$ & $38.3(30.0,49.5)$ & 51 & $24.8(18.9,30.7)$ \\
\hline High latitude, January & 17 & 0 & 0 & $56.5(46.8,62.8)$ & $56.5(46.8,62.8)$ & 0 & 0.0 \\
\hline Medium latitude, October & 146 & 8 & $10.9(7.5,17.8)$ & $50.3(42.8,58.3)$ & $50.5(42.8,58.5)$ & 3 & $2.1(0,4.4)$ \\
\hline Medium latitude, November & 198 & 26 & $8.0(6.8,12.8)$ & $49.3(38.8,57.5)$ & $51.0(40.3,59.5)$ & 14 & $7.1(3.5,10.6)$ \\
\hline Medium latitude, December & 73 & 6 & $8.9(7.3,15.8)$ & $41.0(31.0,50.8)$ & $41.3(32.0,52.0)$ & 16 & $21.9(12.4,31.4)$ \\
\hline Medium latitude, January & 31 & 3 & $8.0(5.8,8.3)$ & $47.8(40.3,56.8)$ & $48.8(40.3,56.8)$ & 3 & $9.7(0,20.1)$ \\
\hline Low latitude, October & 38 & 3 & $9.3(8.3,32.5)$ & $52.1(42.3,61.5)$ & $55.6(42.8,64.8)$ & 0 & 0.0 \\
\hline Low latitude, November & 241 & 35 & $10.8(7.0,17.5)$ & $51.3(42.3,60.5)$ & $53.3(43.5,62.5)$ & 7 & $2.9(0.8,5.0)$ \\
\hline Low latitude, December & 188 & 18 & $12.9(8.0,22.3)$ & $50.3(38.4,61.9)$ & $52.3(41.4,63.0)$ & 7 & $3.7(1.0,6.4)$ \\
\hline Low latitude, January & 18 & 0 & 0 & $51.4(41.0,56.5)$ & $51.4(41.0,56.5)$ & 0 & 0.0 \\
\hline
\end{tabular}

* Total vitamin D concentration $<30 \mathrm{nmol} / \mathrm{L}$ is defined as vitamin D deficiency. \# number. Wilcoxon rank sum test or Kruskal-Wallis H rank sum test for comparing the difference of $25(\mathrm{OH}) \mathrm{D}$ concentration. Chi-square test for comparing the difference of $25(\mathrm{OH}) \mathrm{D}$ deficiency. ${ }^{\mathrm{a}} p<0.05$ (Wilcoxon rank sum test or Kruskal-Wallis $\mathrm{H}$ rank sum test). ${ }^{\mathrm{b}} p<0.05$ (chi-square test). CI, confidence interval.

\subsection{Association of Vitamin D2 Detected and 25(OH)D Concentration}

The associated factors of $25(\mathrm{OH}) \mathrm{D}$ concentration were shown in Table 2. Adjusted for age, sex, ethnic, residential area, outdoor time, combination of latitude and month studied, the expected $25(\mathrm{OH}) \mathrm{D}$ concentration was $8.48 \mathrm{nmol} / \mathrm{L}$ higher in the group with vitamin D2 detected than the group without vitamin D2 detected $(p<0.001)$.

\subsection{Relationship between Vitamin D2 Detected and Vitamin D Deficiency}

Influencing factors of vitamin D deficiency are shown in Table 3. The AUC (area under roc curve) of the multivariate logistic regression model was 0.81 . Adjusted for age, sex, ethnic, residential area, combination of latitude and month studied, the children without $25(\mathrm{OH}) \mathrm{D} 2$ detected had a $4.20(1.64,10.77)$ times higher odds of vitamin D deficiency than those with $25(\mathrm{OH}) \mathrm{D} 2$ detected. 
Table 2. Adjusted association of vitamin D2 detected and $25(\mathrm{OH}) \mathrm{D}$ concentration of children aged 3-5 years in China.

\begin{tabular}{|c|c|c|c|}
\hline Risk Factors & $n$ & $\beta$ (SE) & $p$ \\
\hline \multicolumn{4}{|l|}{ Vitamin D2 detected } \\
\hline Yes & 156 & Ref. & - \\
\hline No & 1279 & $-8.48(1.25)$ & $<0.001$ \\
\hline \multicolumn{4}{|l|}{ Age } \\
\hline 3 year & 483 & Ref. & - \\
\hline 4 year & 481 & $-5.21(0.94)$ & $<0.001$ \\
\hline 5 year & 471 & $-5.33(0.96)$ & $<0.001$ \\
\hline \multicolumn{4}{|l|}{ Sex } \\
\hline Boy & 720 & Ref. & - \\
\hline Girl & 715 & $-4.29(0.77)$ & $<0.001$ \\
\hline \multicolumn{4}{|l|}{ Ethnicity group } \\
\hline Han & 1199 & Ref. & - \\
\hline Muslin & 31 & $-7.01(2.73)$ & 0.010 \\
\hline Others & 204 & $-2.81(1.19)$ & 0.019 \\
\hline \multicolumn{4}{|l|}{ Residential area } \\
\hline Rural & 717 & Ref. & - \\
\hline Urban & 718 & $-3.17(0.85)$ & $<0.001$ \\
\hline \multicolumn{4}{|l|}{ Outdoor time (per day) } \\
\hline$\geq 2 \mathrm{~h}$ & 1033 & Ref. & - \\
\hline$<2 \mathrm{~h}$ & 395 & $-1.68(0.90)$ & 0.061 \\
\hline \multicolumn{4}{|l|}{ Latitude and survey month } \\
\hline High latitude, October & 105 & $8.62(1.85)$ & $<0.001$ \\
\hline High latitude, November & 174 & $8.03(1.51)$ & $<0.001$ \\
\hline High latitude, December & 206 & Ref. & - \\
\hline High latitude, January & 17 & $11.41(3.74)$ & 0.002 \\
\hline Medium latitude, October & 146 & $10.37(1.67)$ & $<0.001$ \\
\hline Medium latitude, November & 198 & $8.34(1.51)$ & $<0.001$ \\
\hline Medium latitude, December & 73 & $3.01(2.02)$ & 0.138 \\
\hline Medium latitude, January & 31 & $14.69(2.83)$ & $<0.001$ \\
\hline Low latitude, October & 38 & $12.49(2.63)$ & $<0.001$ \\
\hline Low latitude, November & 241 & $12.97(1.42)$ & $<0.001$ \\
\hline Low latitude, December & 188 & $12.90(1.53)$ & $<0.001$ \\
\hline Low latitude, January & 18 & $10.63(3.68)$ & 0.004 \\
\hline
\end{tabular}

Ref. = group of reference. Model: multiple linear regression model. Significant difference $(p<0.05)$.

Table 3. Relationship between vitamin D2 detected and vitamin D deficiency of children aged 3-5 years in China.

\begin{tabular}{cccc}
\hline Risk Factors & Vitamin D Deficiency & OR (95\% CI) & $p$ \\
\hline Vitamin D2 detected & $5 / 156$ & Ref. & - \\
Yes & $122 / 1279$ & $4.20(1.64,10.77)$ & 0.003 \\
No & & & \\
Sex & $48 / 720$ & Ref. & - \\
Boy & $79 / 715$ & $2.17(1.45,3.26)$ & $<0.001$ \\
Girl & & & \\
Ethnicity group & $97 / 1199$ & Ref. & - \\
Han & $9 / 31$ & $3.57(1.48,8.61)$ & 0.005 \\
Muslin & $21 / 204$ & $1.81(1.01,3.25)$ & 0.048 \\
Others & & & \\
Residential area & $35 / 717$ & Ref. & - \\
Rural & $92 / 718$ & $2.18(1.38,3.45)$ & $<0.001$ \\
Urban & &
\end{tabular}


Table 3. Cont.

\begin{tabular}{cccc}
\hline Risk Factors & Vitamin D Deficiency & OR (95\% CI) & $p$ \\
\hline Latitude and survey month & & & \\
High latitude, October & $5 / 105$ & $0.23(0.09,0.64)$ & 0.005 \\
High latitude, November & $21 / 174$ & $0.39(0.22,0.69)$ & 0.001 \\
High latitude, December & $51 / 206$ & Ref. & - \\
High latitude, January & $0 / 17$ & - & - \\
Medium latitude, October & $3 / 146$ & $0.08(0.02,0.27)$ & $<0.001$ \\
Medium latitude, November & $14 / 198$ & $0.29(0.15,0.56)$ & $<0.001$ \\
Medium latitude, December & $16 / 73$ & $0.87(0.44,1.71)$ & 0.678 \\
Medium latitude, January & $3 / 31$ & $0.34(0.10,1.21)$ & 0.095 \\
Low latitude, October & $0 / 38$ & - & - \\
Low latitude, November & $7 / 241$ & $0.09(0.04,0.20)$ & $<0.001$ \\
Low latitude, December & $7 / 188$ & $0.12(0.05,0.29)$ & $<0.001$ \\
Low latitude, January & $0 / 18$ & - & - \\
\hline
\end{tabular}

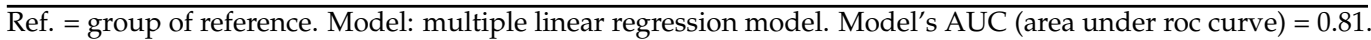
Significant difference $(p<0.05)$. CI, confidence interval.

\section{Discussion}

The prevalence of vitamin D deficiency $(25(\mathrm{OH}) \mathrm{D}<30 \mathrm{nmol} / \mathrm{L})$ was $8.9 \%$ overall and more than one-fifth of the children had vitamin D deficiency at latitude above $30^{\circ} \mathrm{N}$ in December. Children with detectable 25(OH)D2 had higher concentration of 25(OH)D and lower odds of vitamin D deficiency.

The prevalence of vitamin D deficiency among Chinese preschool children in this study was $8.9 \%$, which was higher than $7.1 \%$ of children aged $1-5$ years in NHANES 2011-2014 [28] and 7\% of children aged 1-6 years old in Toronto (latitude 43.4 ${ }^{\circ} \mathrm{N}$ ) [29]. The prevalence of $25(\mathrm{OH}) \mathrm{D}<50 \mathrm{nmol} / \mathrm{L}$ was $21.9 \%$ of children aged $2-5$ years in a study from Hangzhou [30] and 15.1\% of children aged 2-6 years in a study from Wenzhou [31], which are in southeastern China with low latitude and more seafood consumption. The prevalence of $25(\mathrm{OH}) \mathrm{D}<50 \mathrm{nmol} / \mathrm{L}$ in Hangzhou of this study was significantly higher than that of children aged 2-5 years in winter and spring in the Hangzhou study ( $49 \%$ vs. $<30 \%$ ). The difference may be due to the fact that the subjects of the two studies were from different sources. The Hangzhou study was based on the children for health examination in Children's Hospital Affiliated to Zhejiang University School of Medicine, while the present study was based on a population sample survey.

Vitamin D deficiency was more common at latitude above $30^{\circ} \mathrm{N}$ in November and December. However, vitamin D deficiency was not severe in October, even in the area of latitude above $35^{\circ} \mathrm{N}$. At the areas of latitude below $30^{\circ} \mathrm{N}$, vitamin D deficiency was not common from October to January. The prevalence of serum $25(\mathrm{OH}) \mathrm{D}<25 \mathrm{nmol} / \mathrm{L}$ ranged from approximately $<1-5 \%$ in the winter/lower latitude subpopulation (November-March, median latitude $32^{\circ} \mathrm{N}$, range $25-41^{\circ} \mathrm{N}$ ) and in summer higher latitude subpopulation (April-October, median latitude $39^{\circ} \mathrm{N}$, range $25-47^{\circ} \mathrm{N}$ ) of adolescents and adults from NHANES III [26]. It was consistent with other studies that strength of sunlight declines with increasing latitude and the sunshine time is longer in summer/fall than in winter/spring [32].

The prevalence of detectable $25(\mathrm{OH}) \mathrm{D} 2$ was $10.9 \%$ of children in the current study, which was similar to NHANES 2007-2010 (11\% in children aged 1-5 years) [27]. In the National Adults Nutrition Survey (NANS) in Ireland with a low limit of quantification $(1.43 \mathrm{nmol} / \mathrm{L}), 78.7 \%$ adults had serum $25(\mathrm{OH}) \mathrm{D} 2$. The median of $25(\mathrm{OH}) \mathrm{D} 2$ concentration $(10.0 \mathrm{nmol} / \mathrm{L})$ in our study was higher than the children age 1-5 years in NHANES $(<5 \mathrm{nmol} / \mathrm{L})$. The P90 value $(6.36 \mathrm{nmol} / \mathrm{L})$ and the $\mathrm{P} 95$ value $(8.19 \mathrm{nmol} / \mathrm{L})$ of $25(\mathrm{OH}) \mathrm{D} 2$ in NHANS were lower than the median of $10.0 \mathrm{nmol} / \mathrm{L}$ in the current study. Therefore, the rate of vitamin D2 detected was slightly lower due to the different LOD, but the concentration of vitamin D2 was higher in Chinese preschool children. 
Adjusting for the effects of other possible factors, the group of 25(OH)D2 undetected was 4.20 times more likely to have vitamin $\mathrm{D}$ deficiency than the detected group. The median total $25(\mathrm{OH}) \mathrm{D}$ was significantly higher in the children with detectable vs. undetectable $25(\mathrm{OH}) \mathrm{D} 2(55.0 \mathrm{nmol} / \mathrm{L}$ vs. $48.3 \mathrm{nmol} / \mathrm{L})$. These suggested that vitamin D2 played an important role in maintaining vitamin D status of Chinese children aged 3-5 years.

Unlike vitamin D3, vitamin D2 must be derived from dietary sources or nutrient supplements. It was generally considered that vitamin D2 was not commonly found in food. Due to the fact that vitamin D2 data are extremely sparce in food composition tables, it is difficult to calculate vitamin D2 intake and the contribution of vitamin D2 to total vitamin D. In the current study, the concentration of 25(OH)D2 was $10.1(7.1,16.0) \mathrm{nmol} / \mathrm{L}$ and total $25(\mathrm{OH}) \mathrm{D}$ was $55.0(46.8,65.8) \mathrm{nmol} / \mathrm{L}$ in the group with detected vitamin $\mathrm{D} 2$. In a study about osteoporotic fractures of men $\geq 65$ years old, $25(\mathrm{OH}) \mathrm{D} 2(18.5 \mathrm{nmol} / \mathrm{L})$ also played an important role to total $25(\mathrm{OH}) \mathrm{D}(64.5 \mathrm{nmol} / \mathrm{L})$ in the group with detected 25(OH)D2 [33]. Vitamin D3 is more appropriate for supplementation or fortification in foods [34] because vitamin D2 might be less effective in raising levels of total 25(OH)D than vitamin D3 [35] and the poor stability of vitamin D2 is worrisome [36,37]. Many supplements are in the form of vitamin D3 and only high-dose, prescription vitamin D formulation is available for vitamin D2 in the United States [33]. In Europe, vitamin D2 is less frequently used for fortification and supplementation [38]. By searching for product information on the internet, the majority of vitamin D supplements on the China market are for vitamin D3. Thus, the serum vitamin D2 in the human body could mainly come from natural food.

Vitamin D2, which is converted by fungal sterol, ergosterol, mainly exists in plant foods. Simon et al. showed that mushrooms are excellent sources of vitamin D2 [39], and vitamin D2 baker's yeast is produced by exposing baker's yeast to ultraviolet light [40]. Mushrooms, fermented food and yeast are commonly consumed in China, which may be related to the high concentration of vitamin D2 in the current study. Interesting, unlike total vitamin D, the rate of vitamin D2 detected was higher in December than in October (not reported in the results), which needs to be further studied.

Our study has some limitations. The prevalence of vitamin D deficiency may be overestimated, as the survey was conducted from October to January, mainly in the winter. In addition, dietary vitamin D2 information was not available to assess its contribution; however, serum 25OHD2 might provide metabolized vitamin D2 contribution for Chinese children aged 3-5 years. Randomized control trials of dietary vitamin D2 intake study remain warranted to assess the effects.

\section{Conclusions}

Overall, vitamin D deficiency is relatively common for children aged 3-5 years in China, especially for those living above $30^{\circ} \mathrm{N}$ latitude in November and December, which could be a focus for vitamin D deficiency interventions. For a proportion of these children, dietary vitamin D2 might contribute to their vitamin D status and dietary vitamin D2 might be considered for improving vitamin $\mathrm{D}$ level of children in this age group in China. In the population with risk of vitamin D deficiency (e.g., high latitude, winter and/or indoor lifestyle), the magnitude of vitamin D2 intake contribution to overall vitamin D status warrants further studies by using longitudinal study designs.

Author Contributions: Investigation, X.P., Z.Y., J.W., Y.D., L.Z., D.Y. and J.L.; formal analysis, X.P. and Z.Y.; writing - original draft preparation, X.P. and Z.Y.; project administration, L.Z. and D.Y.; writing-review and editing Z.Y. and J.L. All authors have read and agreed to the published version of the manuscript.

Funding: This research was funded by National Special Program for Science and Technology Basic Resources Investigation of China, Grant Number 2017FY101100 and 2017FY101103; The Major Program for Healthcare Reform from the Chinese National Health and Family Planning Commission. 
Institutional Review Board Statement: The study was approved by the medical ethics committee of National Institution for Nutrition and Health (formerly National Institute of Nutrition and Food Safety), Chinese Center for Disease Control and Prevention (2013-018).

Informed Consent Statement: Informed consent was obtained from all subjects involved in the study.

Data Availability Statement: The datasets generated or analyzed during the current study are not publicly available due to the data management requirements of our institution, but are available from the corresponding author on reasonable request.

Acknowledgments: We thank all of the participants in the study, and all of the staff devoting their time and energy to Chinese national nutrition and health surveillance in 2013.

Conflicts of Interest: The authors declare no conflict of interest.

$\begin{array}{ll}\text { Abbreviations } \\ \text { CNNHS } & \begin{array}{l}\text { Chinese national nutrition and health surveillance } \\ \text { Chinese Yuan }\end{array} \\ \text { CNY } & \begin{array}{l}\text { coefficients of variations } \\ \text { CVs }\end{array} \\ \text { IOM } & \text { institution of medicine } \\ \text { IQR } & \text { inter-quartile range } \\ \text { LC-MS } & \text { liquid chromatography- mass spectrometry } \\ \text { LOD } & \text { limit of detection } \\ \text { OR } & \text { Odd ratio } \\ \text { SLE } & \text { significance level for entry } \\ \text { SLS } & \text { significance level for stay } \\ \text { WHZ } & \text { weight-for-height Z-score } \\ \text { 95\% CI } & 95 \% \text { confidence interval }\end{array}$

\section{References}

1. Birna, T.; Ingibjorg, G.; Laufey, S.; Gestur, P.; Bryndis, B.; Inga, T. Vitamin D Intake and Status in 6-Year-Old Icelandic Children Followed up from Infancy. Nutrients 2016, 8, 75.

2. Cranney, A.; Horsley, T.; O'Donnell, S.; Weiler, H.; Mamaladze, V. Effectiveness and safety of vitamin D in relation to bone health. Evid. Rep. Technol. Assess. 2007, 158, 1-235.

3. Bezrati, I.; Hammami, R.; Fradj, M.B.; Martone, D.; Padulo, J.; Feki, M.; Chaouachi, A.; Kaabachi, N. Association of plasma 25-hydroxyvitamin D with physiological performances in physically active children. Appl. Physiol. Nutr. Metab. 2016, 41, 1124-1128. [CrossRef] [PubMed]

4. Hujoel, P.P. Vitamin D and dental caries in controlled clinical trials: Systematic review and meta-analysis. Nutr. Rev. 2013, 71, 88-97. [CrossRef]

5. Ji-Hyeon, S.; Byung-Guk, K.; Young, K.B.; Whan, K.S.; Won, K.S.; Hojong, K. Is there an association between vitamin D deficiency and adenotonsillar hypertrophy in children with sleep-disordered breathing? BMC Pediatrics 2018, 18, 196.

6. Michelle, S.; Maguire, J.L.; Russell, M.L.; Marek, S.; Walter, S.D.; Mark, L. Low serum 25-hydroxyvitamin D level and risk of upper respiratory tract infection in children and adolescents. Clin. Infect. Dis. 2013, 57, 392-397.

7. Maxwell, C.S.; Carbone, E.T.; Wood, R.J. Better newborn vitamin D status lowers RSV-associated bronchiolitis in infants. Nutr. Rev. 2012, 70, 548-552. [CrossRef]

8. Kelishadi, R.; Farajzadegan, Z.; Bahreynian, M. Association between vitamin D status and lipid profile in children and adolescents: A systematic review and meta-analysis. Int. J. Food Sci. Nutr. 2014, 65, 404-410. [CrossRef] [PubMed]

9. Feitong, W.; Juonala, M.; Pitkänen, N.; Jula, A.; Lehtimäki, T.; Sabin, M.A.; Pahkala, K.; Hutri-Kähönen, N.; Kähönen, M.; Laitinen, T. Both youth and long-term vitamin $\mathrm{D}$ status is associated with risk of type 2 diabetes mellitus in adulthood: A cohort study. Ann. Med. 2017, 50, 74-82.

10. Tomaino, K.; Romero, K.M.; Robinson, C.L.; Baumann, L.M.; Hansel, N.N.; Pollard, S.L.; Gilman, R.H.; Mougey, E.; Lima, J.J.; Checkley, W. Association Between Serum 25-Hydroxy Vitamin D Levels and Blood Pressure Among Adolescents in Two Resource-Limited Settings in Peru. Am. J. Hypertens. 2015, 8, 1017-1023. [CrossRef]

11. Per, T.; Peter, U.; Martin, H.; Henry, S.; Darryl, E.; Mikael, N. Season of birth, neonatal vitamin D status, and cardiovascular disease risk at 35 y of age: A cohort study from Sweden. Am. J. Clin. Nutr. 2014, 99, 472-478.

12. Karpiński, M.; Galicka, A.; Milewski, R.; Popko, J.; Badmaev, V.; Stohs, S.J. Association between Vitamin D Receptor Polymorphism and Serum Vitamin D Levels in Children with Low-Energy Fractures. J. Am. Coll. Nutr. 2017, 36, 64-71. [CrossRef] [PubMed]

13. Hu, Y.; Chen, J.; Wang, R.; Li, M.; Yun, C.; Li, W.; Yang, Y.; Piao, J.; Yang, X.; Yang, L. Vitamin D Nutritional Status and its Related Factors for Chinese Children and Adolescents in 2010-2012. Nutrients 2017, 9, 1024. [CrossRef] 
14. Prietl, B.; Treiber, G.; Pieber, T.; Amrein, K. Vitamin D and Immune Function. Proc. Nutr. Soc. 1991, 50, 251-262. [CrossRef]

15. Lips, P. Worldwide status of vitamin D nutrition. J. Steroid Biochem. Mol. Biol. 2010, 121, 297-300. [CrossRef] [PubMed]

16. Dunlop, E.; Cunningham, J.; Sherriff, J.L.; Lucas, R.M.; Greenfield, H.; Arcot, J.; Strobel, N.; Black, L.J. Vitamin D 3 and 25-Hydroxyvitamin $\mathrm{D}_{3}$ Content of Retail White Fish and Eggs in Australia. Nutrients 2017, 9, 647. [CrossRef] [PubMed]

17. Barvencik, F.; Amling, M. Vitamin D metabolism of the bone. Der Orthopäde 2015, 44, 686. [CrossRef]

18. Cashman, K.D.; O'Sullivan, S.M.; Karen, G.; Michelle, R. Contribution of Vitamin D2 and D3 and Their Respective 25-Hydroxy Metabolites to the Total Vitamin D Content of Beef and Lamb. Curr. Dev. Nutr. 2020, 7, nzaa112. [CrossRef]

19. Tripkovic, L.; Lambert, H.; Hart, K.; Smith, C.P.; Bucca, G.; Penson, S.; Chope, G.; Hypponen, E.; Berry, J.; Vieth, R. Comparison of vitamin D2 and vitamin D3 supplementation in raising serum 25-hydroxyvitamin D status: A systematic review and meta-analysis. Am. J. Clin. Nutr. 2012, 95, 1357-1364. [CrossRef]

20. Yu, D.M.; Zhao, L.Y.; Yang, Z.Y.; Chang, S.Y.; Yu, W.T.; Fang, H.Y.; Wang, X.; Liang, X.F.; Yu, D.; Guo, Q.Y.; et al. Comparison of Undernutrition Prevalence of Children under 5 Years in China between 2002 and 2013. Biomed. Environ. Sci. 2016, 29, 16-176.

21. Duan, Y.; Pang, X.; Yang, Z.; Wang, J.; Lai, J. Association between Dairy Intake and Linear Growth in Chinese Pre-School Children. Nutrients 2020, 12, 2576. [CrossRef]

22. Eyles, D.W.; Feron, F.; Cui, X.; Kesby, J.P.; Harms, L.H.; Ko, P.; McGrath, J.J.; Burne, T.H.J. Developmental vitamin D deficiency causes abnormal brain development. Psychoneuroendocrinology 2009, 34, S247-S257. [CrossRef]

23. Sempos, C.T.; Binkley, N. 25-HydroxyVitamin D assay standardisation and Vitamin D guidelines paralysis. Public Health Nutr. 2020, 23, 1153-1164. [CrossRef]

24. Available online: https://www.who.int/toolkits/child-growth-standards/standards (accessed on 12 November 2021).

25. Available online: https://www.who.int/tools/growth-reference-data-for-5to19-years (accessed on 12 November 2021).

26. Looker, A.C.; Dawson-Hughes, B.; Calvo, M.S.; Gunter, E.W.; Sahyoun, N.R. Serum 25-hydroxyvitamin D status of adolescents and adults in two seasonal subpopulations from NHANES III. Bone 2002, 30, 771-777. [CrossRef]

27. Schleicher, R.L.; Sternberg, M.R.; Looker, A.C.; Yetley, E.A.; Lacher, D.A.; Sempos, C.T.; Taylor, C.L.; Durazo-Arvizu, R.A.; Maw, K.L.; Pfeiffer, C.M.; et al. National Estimates of Serum Total 25-Hydroxyvitamin D and Metabolite Concentrations Measured by Liquid Chromatography-Tandem Mass Spectrometry in the US Population during 2007-2010. J. Nutr. 2016, 146, $1051-1061$. [CrossRef] [PubMed]

28. Herrick, K.A.; Storandt, R.J.; Joseph, A.; Pfeiffer, C.M.; Schleicher, R.L.; Gahche, J.J.; Nancy, P. Vitamin D status in the United States, 2011-2014. Am. J. Clin. Nutr. 2019, 110, 150-157. [CrossRef]

29. Lee, G.J.; Birken, C.S.; Parkin, P.C.; Lebovic, G.; Chen, Y.; L'Abbé, M.R.; Maguire, J.L. Consumption of non-cow's milk beverages and serum vitamin D levels in early childhood. Can. Med. Assoc. J. 2014, 186, 1287-1293. [CrossRef] [PubMed]

30. Zhu, Z.; Zhan, J.; Shao, J.; Chen, W.; Chen, L.; Li, W.; Ji, C.; Zhao, Z. High prevalence of vitamin D deficiency among children aged 1 month to 16 years in Hangzhou, China. BMC Public Health 2012, 12, 126. [CrossRef]

31. Wang, L.L.; Wang, H.Y.; Wen, H.K.; Tao, H.Q.; Zhao, X.W. Vitamin D status among infants, children, and adolescents in southeastern China. J. Zhejiang Univ. Sci. B 2016, 17, 545-552. [CrossRef]

32. Mays, S.; Brickley, M. Vitamin D deficiency in bioarchaeology and beyond: The study of rickets and osteomalacia in the past. Int. J. Paleopathol. 2018, 23, 1-5. [CrossRef]

33. Swanson, C.M.; Nielson, C.M.; Shrestha, S.; Lee, C.G.; Barrett-Connor, E.; Jans, I.; Cauley, J.A.; Boonen, S.; Bouillon, R.; Vanderschueren, D. Higher 25(OH)D2 is associated with lower 25(OH)D3 and 1,25(OH)2D3. J. Clin. Endocrinol. Metab. 2014, 99, 1069. [CrossRef]

34. Houghton, L.A.; Vieth, R. The case against ergocalciferol (vitamin D2) as a vitamin supplement. Am. J. Clin. Nutr. 2006, 84, 694-697. [CrossRef] [PubMed]

35. Romagnoli, E.; Mascia, M.L.; Cipriani, C.; Fassino, V.; Mazzei, F.; D’Erasmo, E.; Carnevale, V.; Scillitani, A.; Minisola, S. Short and long-term variations in serum calciotropic hormones after a single very large dose of ergocalciferol (vitamin D2) or cholecalciferol (vitamin D3) in the elderly. J. Clin. Endocrinol. Metab. 2008, 93, 3015-3020. [CrossRef]

36. Grady, L.T.; Thakker, K.D. Stability of solid drugs: Degradation of ergocalciferol (vitamin D2) and cholecalciferol (vitamin D3) at high humidities and elevated temperatures. J. Pharm. Sci. 1980, 69, 1099-1102. [CrossRef] [PubMed]

37. Huber, W.; Barlow, O.W. Chemical and Biological Stability of Crystalline Vitamins D2 And D3 And Their Derivatives. J. Biol. Chem. 1943, 149, 125-137. [CrossRef]

38. Lehmann, U.; Hirche, F.; Stangl, G.I.; Hinz, K.; Westphal, S.; Dierkes, J. Bioavailability of vitamin d2 and d3 in healthy volunteers, a randomized placebo-controlled trial. J. Clin. Endocrinol. Metab. 2013, 98, 4339-4345. [CrossRef]

39. Simon, R.R.; Phillips, K.M.; Horst, R.L.; Munro, I.C. Vitamin D Mushrooms: Comparison of the Composition of Button Mushrooms (Agaricus bisporus) Treated Postharvest with UVB Light or Sunlight. J. Agric. Food Chem. 2011, 59, 8724-8732. [CrossRef] [PubMed]

40. Fraser, L.M. Food Additives Permitted for Direct Addition to Food for Human Consumption; Vitamin D2. Federal Register. 2009, 74, 11019-11022. 